\title{
Research Advances in Anammox Granular Sludge
}

\author{
Yuanyuan Zhang, Xuehong Zhang, Wenjie Zhang \\ Guangxi Scientific Experiment Center of Mining, \\ College of Environmental Science and Engineering, \\ Guilin University of Technology, 12, JianganRoad, Guilin, 541004, China
}

\begin{abstract}
Anaerobic ammonium oxidation (Anammox), which is assumed to be an appropriate process for the treatment of nitrogen-rich wastewater, is a promising and novel biological nitrogen removal process with attractive application prospects. However, the drawback of this cost-effective process is the low growth rate of Anammox bacteria. So the Anammox process are often operated at a long solids retention time (SRT) in order to cultivate biomass successfully. The granulation of Anammox biomass offers an effective strategy to retain the biomass in Anammox reactors compared with other formation of sludge. This paper reviewed the up-to-date research progress, the property, the cultivation, as well as the application of Anammox granular sludge worldwide.
\end{abstract}

Keywords-Anammox granular sludge; granulation; wastewater treatment

\section{INTRODUCTION}

Anaerobic ammonium oxidation (ANAMMOX) is a promising biotechnology for the treatment of ammonium-rich wastewater [1]. Anammox bacteria can oxidize ammonium into dinitrogen with nitrite as electron as acceptor under anoxic condition without external carbon source.As an innovative and eco-friendly biological nitrogen removal alternative compared to traditional nitrification/denitrification process[2], Anammox has the advantages of a higher nitrogen removal rate (NRR), lower operational costs, and smaller volume requirements[1,3]. Since its initial discovery, Anammox has been extensively investigated all over the world.

However, there are some limitations in the extensive application of Anammox technology. The main drawbacks of this novel technology are the long start-up period and the low growth rate of the bacteria [4]. The long start-up period is one of the major obstacles for the practical application of Anammox technology, even though it has been studied for two decades. The doubling time of Anammox microorganism at $30-40^{\circ} \mathrm{C}$ was reported to be approximately 10-14 days[5].

Anammox biomass in reactor systems have many categories: free cell or flocculent sludge, biofilm and granular sludge. Due to the slow growth rate of the Anammox bacteria, the reactors are usually operated at an extremely long sludge retention time (SRT) in the system in order to cultivate the bacteria successfully [6]. In the free cell or flocculent sludge Anammox systems, the biomass are easily to be washed out. Because Anammox bacteria have a trend to grow in aggregates[7], granule systems have advantages to the cultivation of Anammox. Since Anammox granule systems can sustain biomass effectively [7,8], this form of systems are used to cultivate the Anammox bacteria frequently [9]. Furthermore, since a very high biomass concentration can be obtained in the system, granular reactors are desirable biological treatment process. It stands for a high transformation of contaminant and a small volume of reactor[10]. The reported high-rate Anammox processes are usually granule systems [1,8,11,12]. Therefore, bacteria growing as granules was considered to be one of the suitable and promising methods for Anammox process.

This review aims to present a detailed comparative summary of research progress, the property, the cultivation, as well as the application of Anammox granules.

\section{RESEARCH PROGRESS OF ANAMMOX GRANULAR SLUDGE}

In 1995, Ammonium oxidation coupled to the reduction of nitrate was discovered in a fluidized denitrification reactor by Mulder et al. [13]. Later this process was demonstrated to be a biochemical reaction and nitrite was supposed to be the optimum electron acceptor[14].

Many researchers focused on the activity of Anammox granules, such as different inoculums, different form of reactors, and high loading rate. Overview of Anammox granular sludge performance has been highlighted in Table 1. An expanded granular sludge bed (EGSB) reactor was started-up successfully by seeding the anaerobic sludge from a brewery wastewater treatment plant by Wang et al.[15] in 2004. After 3 months operation, the granular sludge was discovered in the reactor, and the ammonium nitrogen could be removed continuously [15]. In 2010, Ni et al.[16] started-up a pilot-scale Anammox reactor successfully in two weeks seeded with exotic mature granules. This research indicated that the granular Anammox reactor possessed high nitrogen removal potential of $27.8 \mathrm{~kg}-\mathrm{N} / \mathrm{m}^{3} / \mathrm{d}$. The microbial community of the granules was quantified to be composed of 91.4-92.4\% Anammox bacteria by real-time polymerase chain reaction. The performance of Anammox at low ambient temperatures inup-flow anaerobic sludge blanket (UASB) reactors was also investigated [17]. By adding $10 \mathrm{~mL}$ highly active Anammox sludge every 2 days, the NRR at $9.1^{\circ} \mathrm{C}$ finally reached $6.6 \mathrm{~kg}-\mathrm{N} / \mathrm{m}^{3} / \mathrm{d}$ [18]. To update, a super high-rate performance with NRR of $74.3-76.7 \mathrm{~kg}-\mathrm{N} / \mathrm{m}^{3} / \mathrm{d}$ was accomplished in the lab-scale Anammox UASB reactors[8].

So far, at least five "Candidatus" Anammox bacterial genera have been identified [19], including Candidatus 
“Anammoxoglobus”, Candidatus "Brocadia”, Candidatus "Jetteniaasiatica", Candidatus "Kueneniastuttgartiensis", and Candidatus "Scalindua". All these bacteria are monophyletic in that they are encompassed within the phylum Planctomycetes.

TABLE I. OVERVIEW OF ANAMMOX GRANULAR SLUDGE PERFORMANCE

\begin{tabular}{|c|c|c|c|c|}
\hline $\begin{array}{l}\text { Reactor } \\
\text { type }\end{array}$ & Inoculum & HRT & $\begin{array}{l}\text { NLR or NRR } \\
\left(\mathrm{kg}-\mathrm{N} / \mathrm{m}^{3} / \mathrm{d}\right)\end{array}$ & Reference \\
\hline SBR & $\begin{array}{l}\text { Anammox } \\
\text { granules }\end{array}$ & $1 d$ & 0.3 (NRR) & $\begin{array}{l}\text { Arrojo et al. } \\
{[20]}\end{array}$ \\
\hline EGSB & $\begin{array}{l}\text { Anammox } \\
\text { granules }\end{array}$ & $1.5 \mathrm{~h}$ & 18.65 (NRR) & $\begin{array}{l}\text { Chen et al. } \\
\text { [21] }\end{array}$ \\
\hline EGSB & $\begin{array}{l}\text { Anaerobic } \\
\text { granules }\end{array}$ & 6-0.3h & 57.14 (NRR) & $\begin{array}{l}\text { Chen et al. } \\
\text { [22] }\end{array}$ \\
\hline UASB & $\begin{array}{l}\text { Anammox } \\
\text { granules }\end{array}$ & - & 1.03 (NLR) & Ni et al. [16] \\
\hline UASB & Activated sludge & $0.28 \mathrm{~h}$ & 2.28 (NRR) & Ma et al. [18] \\
\hline UASB & $\begin{array}{l}\text { Anaerobic } \\
\text { granules }\end{array}$ & $0.2 \mathrm{~h}$ & $\begin{array}{l}74.3-76.6 \\
(\mathrm{NRR})\end{array}$ & Tang et al. [8] \\
\hline
\end{tabular}

\section{THE PROPERTY OF ANAMMOX GRANULAR SLUDGE}

The properties of Anammox granular sludge were affected by the shape of the reactors, hydrodynamic shear force, nitrogen loading rate (NLR), and some other factors. The different condition leading to the discrepancy of the Anammox granules. The characteristics of granular sludge such as heterotrophic aerobic granules, anaerobic granules, denitrifying granules, and hydrogen-producing granule shave been reported extensively. In case of Anammox granules, the diameter, settling property, density, morphology, color, and specific Anammox activity (SAA) have been investigated.

\section{A. Diameter}

The diameter of Anammox granules could be employed as an indicator of reactor performance. Diameter has great relationship with the settleability of Anammox granules. In addition, high settleability led to the effective performance of reactor. The Anammox granules could be divided into setting granules and floating granules. The research carried out by Lu et al. [23] indicated that, the average diameter of setting granules $(2.96 \pm 0.99 \mathrm{~mm})$ were much smaller than the average diameter of floating granules $(4.58 \pm 1.22 \mathrm{~mm})$. Based on their settling model, controlling Anammox granules with diameter of $1.75-4.00 \mathrm{~mm}$ were supposed to be the optimal for the Anammox process[23]. Another research indicated that the diameter of Anammox granules should be controlled above $2.20 \mathrm{~mm}$ to avoid the floatation of the granules[24]. The increasing diameter of Anammox granules would leading to the decreasing density and the floatation of biomass.

\section{B. Settling property}

The granulation of Anammox biomass offers an effective strategy to retain the biomass in Anammox reactors due to its good settlling ability $[6,20]$. The settling velocity of Anammox granules has close relationship with their diameter and density according to the well-known Stokes equation. Only the settle velocity of settled Anammox granules could be measured since the floating granules did not settle. The increasing diameter and density of the granules leading to the increase of settling velocity. The settling velocity of anaerobic granular sludge was reported to be approximately $60 \mathrm{~m} / \mathrm{h}$ [25]. As for Anammox granules, the settling velocities of $73-88 \mathrm{~m} / \mathrm{h}$ were observed in a UASB reactor[8], which were a little higher than anaerobic granular sludge. Chen et al.[26] reported that Anammox granular sludge with a poor settling ability could lead to unstable operation in the Anammox systems. Some other characteristics, such as roundness, sphericity and mass shape factors, can also influence the settling velocity of Anammox granules.

\section{Density}

The density of Anammox granules is proportional to the performance of reactor. The granules density of $1.03 \mathrm{~g} / \mathrm{mL}$ was obtained by Tang et al.[8]. Franco et al. measured the specific density of Anammox granules, higher density of Anammos granules (91-120 g-VSS/L-granules) was observed compared to the aerobic granules (40-70 g-VSS/L-granules). The density and morphological factors of Anammox granules are probably related to their diameter. The density of Anammox granules decreased with the increase of their diameter.In the range of experiment, the influence of diameter on the settlability of Anammox granules seemed greater than that of density. However, it was the density that finally determined the settlability of Anammox granules.

\section{Morphology}

The morphology of Anammox granules could be observed via scanning electron micrograph (SEM) and transmission electron micrograph (TEM). The ANAMMOX granules were sphere-like in three dimensional shapes. The research carried out by $\mathrm{Lu}$ et al.[24] showed that the Anammox granules were irregular in shape and uneven on surface, and their structure included granule, subunit, microbial cell cluster and single cell. Wang et al.[15] studied the morphology and inner structure of the Anammox granules in an EGSB reactor. Their research illustrated that the Anammox granules were relatively regular in shape, more or less spherical particles with a smooth surface after 3months operation[15]. Granules consisted of a number of cavities, which could be the gas vents of nitrogen production[15]. Tang et al. [8] indicated that Anammox granules was described as a cauliflower-like shape; surface of Anammox granules consisted of spherical bacteria and elliptical bacteria; hardly any bacilli and filamentous bacteria was observed in the reactor, indicating the dominate role of Anammox bacteria.

\section{E. Color}

The characteristics of unique carmine color of Anammox granules has also drawn considerable attention for the process optimization, which could be an indicator of high activity Anammox granules. The color of Anammox 
granules varies from carmine to brownish, or black, but high load Anammox granules are usually carmine in appearance. The color of granules associated with the denitrogen performance of the reactor. Therefore, the role and the concentration of Hemec was revealed by some researchers, which contributed the granular sludge with the unique carmine color. The carmine color of the granules was supposed to due to the high content of Hemec, grey color due to the low content and black due to the inexistence of Hemec.

\section{F. Specific Anammox activity (SAA)}

The granular sludge characterized by high activity plays a pivotal role in the performance of high-rate bioreactors. The SAA of the biomass was practically constant and around $0.4 \mathrm{~g}-\mathrm{N} / \mathrm{g}-\mathrm{VSS} / \mathrm{d}$ in a SBR, and the average Feret diameter of the formed granules was $0.64 \mathrm{~mm}[20]$. Dapena et al.[6] reported that averaged maximum specific activities measured in batch experiments were 0.9 and 0.44 g-N/g-VSS/d for in a gas-lift reactor and a SBR, respectively. When the maximum specific activity was exceeded, the system became unstable and biomass started to float. Jin et al. [17] investigated the SAA at different temperature, the maximum SAA of $6.12 \mathrm{mg}-\mathrm{N} / \mathrm{g}-\mathrm{VSS} / \mathrm{h}$ was obtained at $35^{\circ} \mathrm{C}$, and SAA gradually reduced with the decrease of temperature.

\section{THE CULTIVATION OF ANAMMOX GRANULAR SLUDGE}

The favorable condition plays a pivotal role in the formation of Anammox granules in order to obtain a stable Anammox population. Based on "Selection pressure theory" [25], the selection pressure was regarded as the sum of the hydraulic loading rate and the gas loading rate plays a vital role in the granulation process of anaerobic biomass.

Granulation of anaerobic sludge has been widely investigated in UASB reactors, where hydrodynamic shear force is primarily due to liquid up-flow velocity and gas production[10]. In the past decades, the feasibility of up-flow UASB technology for removing high-strength organic wastes from industrial wastewater has been demonstrated sufficiently. $\mathrm{Ni}$ et al. [27] investigated the substrate removal kinetics in a pilot-scale Anammox granular reactor by inoculating Anammox granules in to an UASB reactor, which was then operated at different hydraulic retention times and nitrogen loading rates. The reactor showed good tolerance to substrate concentration shock while it was affected significantly by hydraulic shock. Molecular techniques confirmed the existence of at least four well-known Anammox species and Anammox cells accounted for $93.7 \%$ of total cells.

SBR is also a suitable system to cultivate Anammox microorganisms. Arrojo et al.[20] studied the influence of shear stress on Anammox process in a SBR. The NLRemployed in the reactor was kept around 0.3 g-N/L/d; the nitrite removal efficiency was $98 \%$ during the majority of the operational period [20].

V. THE APPLICATION OF ANAMMOX GRANULAR SLUDGE Since the initial discovery of Anammox process,
Anammox has been extensively researched as a promising method for nitrogen removal. Anammox granules has been successfully applied at the laboratory scale, pilot scale and full scale to the treatment of ammonium-rich wastewater. The engineering application of Anammox process is highly attractive due to its unique pathway entails significant advantages compared to classical nitrification/denitrification. In Anammox process, the organic carbon source requirements decreased by $100 \%$, aeration requirements approximately decreased by $60 \%$ and sludge production by $90 \%$.

In Rotterdam, the Netherlands, first full-scale granular sludge Anammox reactor was started-up successfully in 2007, which took 3.5 years, much longer than the expected 2 years initially[1]. The modified UASB was employed in this process and finally NRR reached $9.5 \mathrm{~kg}-\mathrm{N} / \mathrm{m}^{3} / \mathrm{d}$. Since then, approximately 30 full-scale reactors have begun operating worldwide. Within the last decade, several technologies have been developed and granular reactors have been successfully implemented in full scale. A granular sludge nitrification/Anammox reactor was employed to improve the effluent quality for industrial wastewater, which was demonstrated on full scale and have been operated stable over 3 years [28]. Furthermore, the reactor volume was saved by 17 times and the electric power was saved by approximately $1.5 \mathrm{GWh}$ per year.

\section{CONCLUSION AND PROSPECT}

This paper presented the research progress on Anamoox granule sludge, the property, the cultivation, as well as the application of Anammox granule sludge. It can be concluded that better performance of Anammox granules could be achieved with the following strategies. (1) Proper diameter results in the good settleability of Anammox granules. (2) Good settle property and density contributed to the high removal efficiency, even at high NLR and short HRT. (3) Relatively high Hemec content contributed to the Anammox granulation which leads to high performance. (4) High value of SAA has great relationship with the reactor performance.

Aside from these, some other issues have been identified, such as foaming, and scaling. The floatation of Anammox granules is still a severe issue that must be solved. The granule floatation would results in unstability or even collapse in the system when high NLR are employed. Precipitation of minerals from influent phosphate and calcium cation could improve the granule density evidently [7], but led to the decrease of the volatile suspended solids (VSS) to suspended solids (SS) simultaneously. In the case of granular Anammox technology, the essential cause of granule floatation remains unclear, and the control strategy for granule floatation has hardly been reported. More concentration should be paid on the control strategy for granule floatation under high NLR in the very near future.

\section{ACKNOWLEDGEMENTS}

The research work was supported by National Natural Science Foundation of China (No. 51108108, No. 
41161075), Guangxi Natural Science Foundation (2013GXNSFCA019018), Guangxi Science and Technology Development Project (1298014-14), the Research Funds of the Guangxi Key Laboratory of Environmental Engineering, Protection and Assessment No. $0901 Z 021$.

\section{REFERENCES}

[1] van der Star WR, Abma WR, Blommers D, Mulder JW, Tokutomi T, Strous M, Picioreanu C\& van Loosdrecht MC, Startup of reactors for anoxic ammonium oxidation, experiences from the first full-scale anammox reactor in Rotterdam. Water Res,41(18),pp.4149-4163,2007.

[2] Van Hulle SWH, Vandeweyer HJP, Meesschaert BD, Vanrolleghem PA, Dejans P\& Dumoulin A, Engineering aspects and practical application of autotrophic nitrogen removal from nitrogen rich streams. Chemical Engineering Journal, 162(1),pp.1-20,2010.

[3] Lackner S, Gilbert EM, Vlaeminck SE, Joss A, Horn H\& van Loosdrecht MC, Full-scale partial nitritation/anammox experiences An application survey. Water Res,55,pp.292-303,2014.

[4] M. Strous JJH, J. G. Kuenen\& M. S. M. Jetten, Thesequencingbatchreactorasapowerfultoolforthestudyofslowlygrowi nganaerobicammoniumoxidizingmicroorganisms.Appl Microbiol Biotechnol, 50, pp.589-596,1998.

[5] Jin R-C, Yang G-F, Yu J-J\& Zheng P, The inhibition of the Anammox process, A review. Chemical Engineering Journal, 197, pp.67-79,2012.

[6] Dapena-Mora A, Campos JL, Mosquera-Corral A, Jetten MS\& Mendez $\mathrm{R}$, Stability of the ANAMMOX process in a gas-lift reactor and a SBR. J Biotechnol, 110(2), pp.159-170,2004.

[7] Trigo C, Campos JL, Garrido JM\& Mendez R, Start-up of the Anammox process in a membrane bioreactor. J Biotechnol, 126(4), pp.475-487,2006.

[8] Tang CJ, Zheng P, Wang CH, Mahmood Q, Zhang JQ, Chen XG, Zhang L\& Chen JW, Performance of high-loaded ANAMMOX UASB reactors containing granular sludge. Water Res, 45(1), pp.135-144,2011.

[9] Lopez H, Puig S, Ganigue R, Ruscalleda M, Balaguer MD\& Colprim J, Start-up and enrichment of a granular anammox SBR to treat high nitrogen load wastewaters. Journal of Chemical Technology and Biotechnology, 83(3), pp.233-241,2008.

[10] Liu Y\& Tay J-H, The essential role of hydrodynamic shear force in the formation of biofilm and granular sludge. Water Research, 36, pp.1653-1665,2002.

[11] Tang CJ, Zheng P, Hu BL, Chen JW\& Wang CH, Influence of substrates on nitrogen removal performance and microbiology of anaerobic ammonium oxidation by operating two UASB reactors fed with different substrate levels. J Hazard Mater, 181(1-3), pp.19-26,2010.

[12] Imajo U, Tokutomi T\& Furukawa K, Granulation of Anammox microorganisms in up-flow reactors. Water Science and Technology, 49(4-6), pp.155-163,2004.
[13] Mulder A, Van de Graaf AA, Robertson LA\& Kuenen JG. Anaerobic ammonium oxidation discovered in a denitrifying fluidized bed reactor. FEMS Microbiol Ecol, 16(3), pp.177-84,1995.

[14] Van de Graaf AA, Mulder A, de Bruijn P, Jetten MSM, Robertson LA\& Kuenen JG. Anaerobic oxidation of ammonium is a biologically mediated process. Appl Environ Microbiol, 61(4), pp.1246-51,1995.

[15] Jianlong W\& Jing K, The characteristics of anaerobic ammonium oxidation (ANAMMOX) by granular sludge from an EGSB reactor. Process Biochemistry, 40(5), pp.1973-1978,2005.

[16] Ni SQ, Gao BY, Wang CC, Lin JG\& Sung S, Fast start-up, performance and microbial community in a pilot-scale anammox reactor seeded with exotic mature granules. Bioresour Technol, 102(3), pp.2448-2454,2011.

[17] Jin R-C, Ma C\& Yu J-J, Performance of an Anammox UASB reactor at high load and low ambient temperature. Chemical Engineering Journal, 232, pp.17-25,2013.

[18] Ma B, Peng Y, Zhang S, Wang J, Gan Y, Chang J, Wang S, Wang S\& Zhu G, Performance of anammox UASB reactor treating low strength wastewater under moderate and low temperatures. Bioresour Technol, 129, pp.606-611,2013.

[19] Jetten MSM, van Niftrik L, Strous M, Kartal B, Keltjens JT\& Op den Camp HJM, Biochemistry and molecular biology of anammox bacteria. Critical Reviews in Biochemistry and Molecular Biology, 44(2-3), pp.65-84,2009.

[20] Arrojo B, Mosquera-Corral A, Campos JL\& Mendez R, Effects of mechanical stress on Anammox granules in a sequencing batch reactor (SBR). J Biotechnol, 123(4), pp.453-463,2006.

[21] Chen T, Zheng P, Shen L, Ding S\& Mahmood Q, Kinetic characteristics and microbial community of Anammox-EGSB reactor. Journal of Hazardous Materials, 190(1-3), pp.28-35,2011.

[22] Chen T, Zheng P, Tang C, Wang S\& Ding S, Performance of ANAMMOX-EGSB reactor. Desalination, 278(1-3), pp.281-287,2011.

[23] Lu HF, Ji QX, Ding S\& Zheng P, The morphological and settling properties of ANAMMOX granular sludge in high-rate reactors. Bioresour Technol, 143, pp.592-597,2013.

[24] Lu HF, Zheng P, Ji QX, Zhang HT, Ji JY, Wang L, Ding S, Chen TT, Zhang JQ\& Tang CJ, The structure, density and settlability of anammox granular sludge in high-rate reactors. Bioresour Technol, 123, pp.312-317,2012

[25] Pol LWH, Dezeeuw WJ, Velzeboer CTM\& Lettinga G, GRANULATION IN UASB-REACTORS. Water Science and Technology,15(8-9),pp.291-304,1983.

[26] Chen J, Ji Q, Zheng P, Chen T, Wang C\& Mahmood Q, Floatation and control of granular sludge in a high-rate anammox reactor. Water Res, 44(11), pp.3321-3328,2010.

[27] Ni S-Q, Sung S, Yue Q-Y\& Gao B-Y, Substrate removal evaluation of granular anammox process in a pilot-scale upflow anaerobic sludge blanket reactor. Ecological Engineering, 38(18),pp.30-36,2012.

[28] Abma WR, Driessen W, Haarhuis R\& van Loosdrecht MCM, Upgrading of sewage treatment plant by sustainable and cost-effective separate treatment of industrial wastewater. Water Science and Technology, 61(7), pp.1715-1722,2010. 